\title{
Euphorbia fischeriana Steud inhibits malignant melanoma via modulation of the phosphoinositide-3-kinase/Akt signaling pathway
}

\author{
MENG-HUA DONG ${ }^{1 *}$, QIAN ZHANG ${ }^{1 *}$, YUAN-YUAN WANG ${ }^{2}$, BAI-SUI ZHOU ${ }^{3}$, YU-FEI SUN $^{1}$ and QIANG FU $^{1}$ \\ ${ }^{1}$ College of Basic Medicine, Binzhou Medical University, Yantai, Shandong 264003; \\ ${ }^{2}$ Department of Oncology, Linyi People's Hospital, Linyi, Shandong 276003; ${ }^{3}$ Department of Bone and Joint Surgery, \\ Yantai Affiliated Hospital of Binzhou Medical University, Yantai, Shandong 264003, P.R. China
}

Received November 27, 2014; Accepted January 14, 2016

DOI: $10.3892 / \mathrm{etm} .2016 .3061$

\begin{abstract}
Euphorbia fischeriana Steud, a traditional Chinese medicine, has been shown to inhibit the growth of various cancers by the induction of apoptosis and cell cycle arrest. The purpose of the present study was to investigate the association between the phosphoinositide-3-kinase $(\mathrm{PI} 3 \mathrm{~K}) /$ protein kinase B (Akt) signaling pathway and the inhibitory effect of Euphorbia fischeriana Steud on the growth and metastasis of melanoma B16 cells in vitro, and the underlying mechanisms. MTT assay results indicated that Euphorbia fischeriana Steud inhibited the growth of B16 cells in a time- and dose-dependent manner. Flow cytometric analysis revealed that Euphorbia fischeriana Steud markedly induced apoptosis of the B16 cells, with arrest at the G0/G1 phase of the cell cycle. In addition, in a Transwell assay Euphorbia fischeriana Steud significantly suppressed the migration of B16 cells. Western blot analysis revealed that the expression levels of phosphatase and tensin homolog (PTEN) were upregulated, and the phosphorylation of Akt was downregulated, which resulted in inhibition of the PI3K/Akt signaling pathway and the eventual suppression of its downstream targets, such as matrix metalloproteinase-2 mRNA, in B16 cells. The results demonstrated that Euphorbia fischeriana Steud inhibited the growth and
\end{abstract}

Correspondence to: Professor Qiang Fu, College of Basic Medicine, Binzhou Medical University, 346 Guanhai Road, Yantai, Shandong 264003, P.R. China

E-mail: qiangfu11@fudan.edu.cn

"Contributed equally

Abbreviations: PI3K, phosphatidyl inositol 3-kinase; Akt, protein kinase B; mTOR, mammalian target of rapamycin; PTEN, phosphatase and tensin homolog deleted on chromosome ten; MMP-2, matrix metalloproteinase

Key words: Euphorbia fischeriana Steud, malignant melanoma, PI3K/Akt signaling pathway, traditional Chinese medicine migration of B16 cells, possibly via modulation of the PI3K/Akt signaling pathway and upregulation of PTEN expression levels, in addition to downregulation of $\mathrm{p}-\mathrm{Akt}$ expression. The aforementioned findings suggest that Euphorbia fischeriana Steud may have broad therapeutic applications in the treatment of malignant melanoma.

\section{Introduction}

Malignant melanoma has become a frequently occurring malignancy with an annual increase of $\sim 3 \%$ (1). The majority $(\sim 90 \%)$ of patients with early detected melanoma are curable; however, the efficiency of clinical drugs in the treatment of patients with advanced metastatic melanoma is $<20 \%$ (2), and the 5-year survival rate is $<5 \%$, with a median survival time of only 2-8 months $(3,4)$. Numerous studies have confirmed that the poor prognosis of malignant melanoma is primarily attributable to the high incidence of distant metastasis and a strong capacity for invasion (5-7). Therefore, the development of more effective therapies for the inhibition of metastasis presents a challenge for the treatment of malignant melanoma.

Chemotherapy has a significant role in the treatment of cancer. However, the majority of chemotherapy drugs also destroy normal cells, leading to adverse effects (8). Therefore, the identification of natural compounds with a wide range of anticancer activities, high selectivity for the destruction of cancer cells and low toxicity of normal cells is of importance in cancer research. Euphorbia fischeriana Steud (also known as lang-du), a herbaceous plant used in traditional Chinese medicine (TCM), has demonstrated inhibitory effects through its capacity to induce apoptosis, suppress growth and cause cell cycle arrest when assessed within several cancer cell lines, including leukemia and prostate cancer $(9,10)$. Results from preliminary studies have indicated that Euphorbia fischeriana Steud inhibits the metastasis of melanoma cells through the regulation of certain metastasis-related gene expression levels $(11,12)$. However, the mechanisms involved have yet to be fully elucidated.

In the present study, the activities of Euphorbia fischeriana Steud against the highly metastatic B16-F10 mouse cell line and its association with the 
phosphoinositide-3-kinase (PI3K)/protein kinase B (Akt) signaling pathway, were investigated.

\section{Materials and methods}

Materials. Dulbecco's modified Eagle's medium (DMEM), penicillin, streptomycin, fetal bovine serum (FBS), 3-(4,5-dimethylthiazol-2-yl)-2,5-diphenyltetrazolium bromide (MTT), trypsin-EDTA and propidium iodide (PI) were purchased from Sigma-Aldrich (St. Louis, MO, USA). Fibronectin was purchased from BD Biosciences (Franklin Lakes, NJ, USA) and Transwell chambers from Costar (Corning Inc., NY, USA). Antibodies against phospho (p)-Akt, phosphatase and tensin homolog (PTEN) and $\beta$-actin were purchased from Cell Signaling Technology, Inc. (Danvers, MA, USA ). Polyacrylamide and the protein assay kits were obtained from Bio-Rad Laboratories, Inc. (Hercules, CA, USA). Western blotting detection reagents were purchased from GE Healthcare Life Sciences (Chalfont, UK). Phospho (p)-Akt, matrix metalloproteinase-2 (MMP-2) and $\beta$-actin primers, and reverse transcription-polymerase chain reaction (RT-PCR) kits (Takara RNA PCR Kit) were purchased from Takara Bio, Inc. (Otsu, Japan).

Extraction of Euphorbia fischeriana Steud. The roots of Euphorbia fischeriana Steud were purchased from Lunan Pharmaceutical (Linyi, China). The powdered roots of Euphorbia fischeriana Steud were extracted by heating in $88 \%$ ethanol at $50^{\circ} \mathrm{C}$. Following precipitation, the cooled solution was filtered and evaporated under reduced pressure to generate a residue. The extract was then suspended in distilled water. After a second precipitation step using water, the supernatant was condensed as an extract of Euphorbia fischeriana Steud for use in the in vitro experiments. The extract contained $\sim 0.53 \%$ jolkinolide (A and $\mathrm{B}), 1.06 \%$ fischeriana (A and B) and flavonoids (1.75\%).

Cell culture and in vitro growth assays. The murine melanoma cell line B16-F10 (B16) was obtained from the American Type Culture Collection (Manassas, VA, USA). The B16 cell line was cultured $\left(3 \times 10^{3}\right.$ cells/well) in DMEM medium containing $10 \%$ heat-inactivated FBS, glutamine $(2 \mathrm{mM}$; Hyclone; GE Healthcare Life Sciences), penicillin (100 U/ml; Sigma-Aldrich) and streptomycin (100 $\mu \mathrm{g} / \mathrm{ml}$; Sigma-Aldrich) at $37^{\circ} \mathrm{C}$ in a humidified incubator with $5 \%$ atmospheric $\mathrm{CO}_{2}$. In the treatment groups, the cells were cultured in DMEM supplemented with $10 \%$ FBS containing 0.8, 1.2, 1.4, 1.6. 1.8 and $2.0 \mathrm{mg} / \mathrm{ml}$ concentrations of Euphorbia fischeriana Steud, whereas cells in the control group were treated with $0.1 \%$ dimethylsulfoxide (DMSO; Sigma-Aldrich). The cell growth was evaluated at 24 and $48 \mathrm{~h}$ after treatments with MTT assay kits. Briefly, the murine melanoma cell line B16 was seeded in 96 -well culture plate $\left(3 \times 10^{3}\right.$ cells/well) and cultivated for 24 h. Euphorbia fischeriana was then added to final concentrations of $0.8,1.2,1.4,1.2,1.8$ and $2.0 \mathrm{mg} / \mathrm{ml}$. After 24 and $48 \mathrm{~h}, 10 \mu 1$ MTT $(10 \mu \mathrm{g} / \mathrm{ml})$ was added to cells in the plate and incubated for $4 \mathrm{~h}$ at $37^{\circ} \mathrm{C}$. Then, $150 \mu \mathrm{l}$ DMSO was added to each well and incubated for $20 \mathrm{~min}$ at room temperature. Following incubation, the absorbance was measured at $570 \mathrm{~nm}$ using a Multiskan MS spectrophotometer (Labsystems, Stockholm, Sweden). Each experiment was replicated three times.

Flow cytometry for analysis of the cell cycle and apoptosis. B16 cells were treated with Euphorbia fischeriana Steud at concentrations of 0 (control, $0.1 \%$ DMSO), $0.8,1.4$ or $2.0 \mathrm{mg} / \mathrm{ml}$ for $24 \mathrm{~h}$. The treated B16 cells were detached in phosphate-buffered saline (PBS)/2 mM trypsin-EDTA, centrifuged at $335 \mathrm{x}$ g for $5 \mathrm{~min}$ at $4^{\circ} \mathrm{C}$ and then resuspended in $250 \mu 1$ hypotonic fluorochrome solution (PBS, $50 \mu \mathrm{g}$ PI, 0.1\% sodium citrate and $0.1 \%$ Triton X-100; Sigma-Aldrich) with RNase A (100 U/ml; Sigma-Aldrich). The DNA content of the cells was analyzed by flow cytometry (BD FACSCalibur; BD Biosciences) with 20,000 events analyzed per sample. Cell cycle distribution and apoptosis were determined on the basis of the DNA content and the sub-G1 cell population, respectively.

In vitro migration assays. B16 cell migration was evaluated using fibronectin-coated polycarbonate filters in modified Transwell chambers. In brief, B16 cells $\left(5 \times 10^{4}\right)$ were seeded onto the upper chamber in $200 \mu \mathrm{l}$ serum-free medium containing Euphorbia fischeriana Steud at the concentrations of 0 (control, $0.1 \%$ DMSO), $0.8,1.4$ or $2.0 \mathrm{mg} / \mathrm{ml}$; the lower compartment was filled with a chemo-attractant $(0.66 \mathrm{ml}$ DMEM supplemented with $10 \%$ FBS). Following a culture period of $6 \mathrm{~h}$ (for the migration assay) at $37^{\circ} \mathrm{C}$, the cells transplanted to the lower surface of the filter were fixed and stained with PI. The cells on the upper side of the filter were removed using a cotton swab. The migrated cells on the underside of the filter were counted and recorded for imaging under a fluorescence microscope (TE2000-U; Nikon Corporation, Tokyo, Japan). Experiments were replicated three times.

Western blot analysis. To determine the effects of Euphorbia fischeriana Steud on the expression levels of PTEN and p-Akt in B16 cells, cells were treated with Euphorbia fischeriana Steud at various concentrations $(0,0.8$, 1.4 or $2.0 \mathrm{mg} / \mathrm{ml}$ ) for $24 \mathrm{~h}$. The treated cells were washed with ice-cold PBS and suspended in lysis buffer (Sigma-Aldrich) on ice for $30 \mathrm{~min}$. Lysates were cleared by centrifugation at $4360 \mathrm{xg}$ for $20 \mathrm{~min}$ at $4^{\circ} \mathrm{C}$. Equal amounts of cell extracts $(60 \mu \mathrm{g})$ were resolved by sodium dodecyl sulfate-polyacrylamide gel electrophoresis, transferred to nitrocellulose membranes (Sigma-Aidrich), and probed with primary antibodies to human PTEN (1:1,000; mouse monoclonal; 14642S; Cell Signaling Technology, Inc.), p-Akt (1:1,000; rabbit polyclonal; 4685S; Cell Signaling Technology, Inc.) and anti- $\beta$-actin (1:1,000; mouse monoclonal; A1978; Sigma-Aldrich) at $4^{\circ} \mathrm{C}$ overnight. The membranes were then washed with T-TBS buffer (Takara Bio, Inc.) 3 times for $10 \mathrm{~min}$, and subsequently incubated at room temperature for $2 \mathrm{~h}$ with goat anti-mouse (1:1,000; sc2005; Santa Cruz Biotechnology, Inc., Dallas, TX, USA) and goat anti-rabbit (1:1,000; sc2004; Santa Cruz Biotechnology, Inc.) horseradish-conjugated secondary antibodies. $\beta$-actin was used as a loading control. After washing with T-TBS buffer 3 times, detection was performed using an enhanced chemiluminescence system (Amersham ECL Western Blotting Detection Reagent; GE Healthcare Life Sciences). 
Table I. Specific primer and probe sequences.

\begin{tabular}{lll}
\hline Gene & Primer and Probe Sequence (5'-3') & Amplicon size (bp) \\
\hline $\begin{array}{l}\text { Phosphorylated-Akt } \\
\text { Forward }\end{array}$ & \\
Reverse & CAATTCCGGTCTGAGGAA \\
Probe & CACATGGGAAGTGTTGTCTG \\
MMP-2 & CTTCTGACGCGCCTGCCCTC \\
Forward & \\
Reverse & CTGGGAGCATGGAGATGGATA \\
Probe & AAGTGAGAATCTCCCCCAACAC \\
$\beta$-actin & ACATGCCTTTGCCCCGGGCA \\
Forward & & \\
Reverse & & 70 \\
Probe & GGAAGCACATCATGGGTCAGA \\
\hline
\end{tabular}

MMP-2, matrix metalloproteinase-2.

$R T$-PCR. Total cellular RNA was extracted from the cells using TRIzol reagent (Invitrogen; Thermo Fisher Scientific, Inc., Waltham, MA, USA) from B16 cells treated with Euphorbia fischeriana Steud at different concentrations (0/0.1\% DMSO vehicle as control, $0.8,1.4$ or $2.0 \mathrm{mg} / \mathrm{ml})$ for $24 \mathrm{~h}$ according to the manufacturer's protocol, and quantified by spectrophotometry (NanoDrop 2000c; Thermo Fisher Scientific, Inc.). An RT-PCR kit was used. Equal amounts of RNA were used for cDNA synthesis in $20 \mu \mathrm{l}$ reactions containing primers (Table I; Bao Biological Engineering Co., Ltd., Dalian, China), $2 \mu$ l total RNA and $\mathrm{ddH}_{2} \mathrm{O}$. Cycling conditions comprised of denaturation for $30 \mathrm{sec}$ at $95^{\circ} \mathrm{C}$, followed by 40 cycles of amplification (at $95^{\circ} \mathrm{C}$ for $5 \mathrm{sec}$ and $60^{\circ} \mathrm{C}$ for $30 \mathrm{sec}$ ) and a final elongation step at $72^{\circ} \mathrm{C}$ for $10 \mathrm{~min}$. To control the PCR reaction components and the integrity of the RNA, $2 \mu \mathrm{l}$ of each cDNA sample was amplified separately by $\beta$-actin specific primers. RT-PCR analyses were carried out in duplicate from $\geq 3$ independent RNA samples. The experimental data was normalized to the $\beta$-actin expression value, and the relative expression levels were calculated using the $2^{-\Delta \Delta \mathrm{Cq}}$ method (13).

Statistical analysis. Data are expressed as mean \pm standard deviation and statistical analysis was conducted using SPSS software, version 13.0 (SPSS, Inc., Chicago, IL, USA). Oneor two-way analysis of variance followed by the Bonferroni post-hoc analysis was performed to establish whether significant differences existed among groups. Values between different treatment groups at different times were compared. Mean concentrations and cell viability or migration (\%) are shown for each group. For all tests, $\mathrm{P}<0.05$ was considered to indicate a statistically significant difference.

\section{Results}

Euphorbia fischeriana Steud inhibits the growth of B16 cells in a time- and dose-dependent manner. The cell growth inhibition rates for $0.8,1.2,1.4,1.6,1.8$ or $2.0 \mathrm{mg} / \mathrm{ml}$

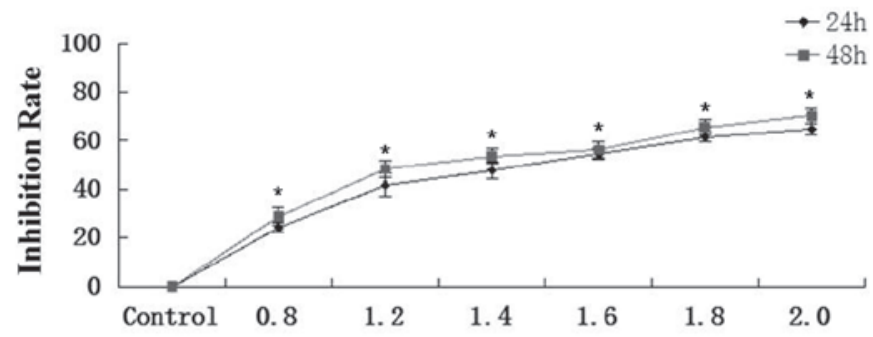

Concentration of Euphorbia Fischeriana Steud (mg/ml)

Figure 1. In vitro effects of Euphorbia fischeriana Steud on the growth of B16 cells. B16 cells were cultured for 24 or 48 h in Dulbecco's modified Eagle's medium containing Euphorbia fischeriana Steud at various concentrations. The effects of Euphorbia fischeriana Steud on cell growth were determined by MTT assay. Statistical analysis was performed using an analysis of variance followed by the Bonferroni test. The figures are representative of three similar experiments. The $\mathrm{IC}_{50}$ values at $24 \mathrm{~h}$ and $48 \mathrm{~h}$ were 1.5 and $1.3 \mathrm{mg} / \mathrm{ml}$, respectively. Results obtained between the control and Euphorbia fischeriana Steud groups differed significantly as a function of Euphorbia fischeriana Steud concentration and time of exposure $(\mathrm{P}<0.05)$. ${ }^{*} \mathrm{P}<0.05$ vs. the control group. MTT, 3-(4,5-dimethylthiazol-2-yl)-2,5-diphenyltetrazolium bromide.

Euphorbia fischeriana Steud at 24 h were 24.2, 41.7, 47.8, 54.7, 61.5 and $64.7 \%$ and at $48 \mathrm{~h}$ were $28.7,48.3,53.7,56.2,65.6$ and $70.2 \%$, respectively (Fig. 1). The plots are representative of three similar experiments performed. The $\mathrm{IC}_{50}$ values at 24 and $48 \mathrm{~h}$ were 1.5 and $1.3 \mathrm{mg} / \mathrm{ml}$, respectively. The in vitro growth assay revealed that Euphorbia fischeriana Steud suppressed the growth of B16 cells in a dose-and time-dependent manner following treatment of the cells with Euphorbia fischeriana Steud at concentrations of $0.8-2.0 \mathrm{mg} / \mathrm{ml}$ for 24 and $48 \mathrm{~h}$, respectively.

Euphorbia fischeriana Steud induces apoptosis and G0/G1 cell cycle arrest in B16 cells in a dose-dependent manner. Flow cytometric analysis (Fig. 2A) revealed that Euphorbia fischeriana Steud $(0,0.8,1.4$ or $2.0 \mathrm{mg} / \mathrm{ml})$ significantly induced the apoptosis of B16 cells at $24 \mathrm{~h}$ with apoptosis rates of $13.97 \pm 0.58,24.26 \pm 0.91$ and $41.82 \pm 0.63 \%$ 

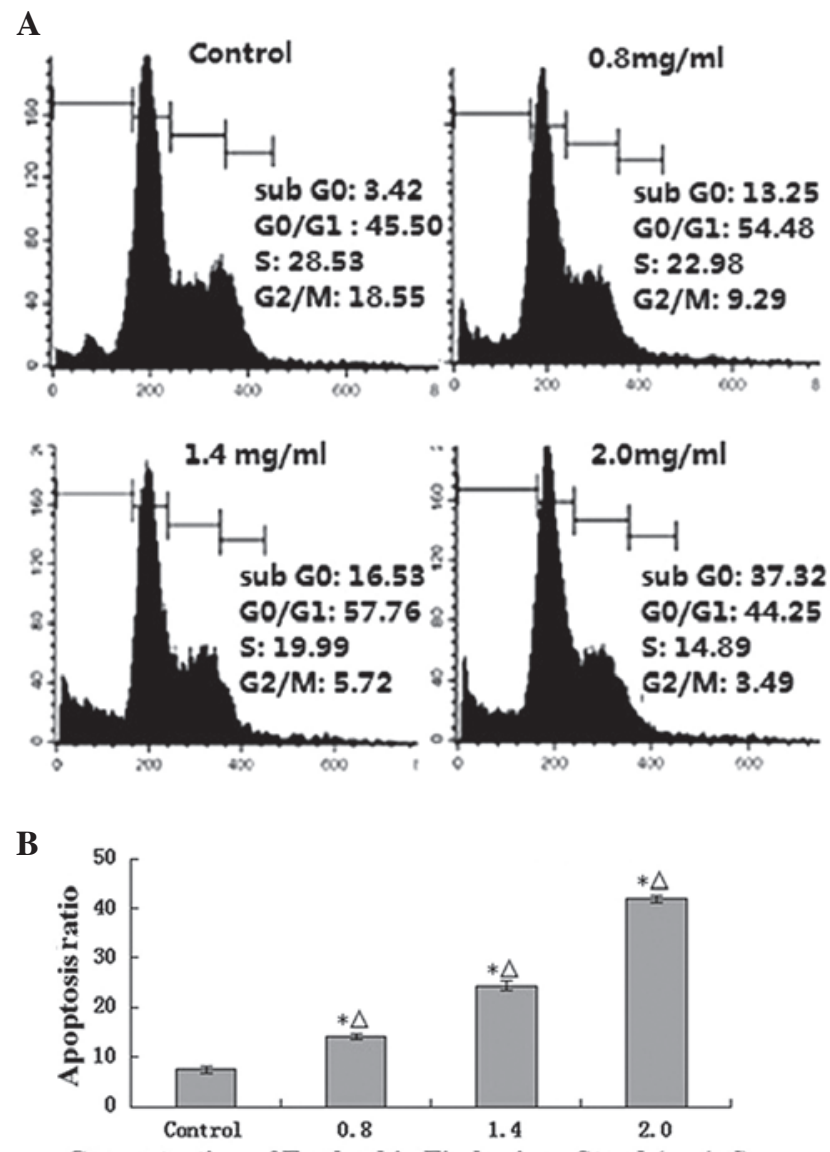

Concentration of Euphorbia Fischeriana Steud (mg/ml)

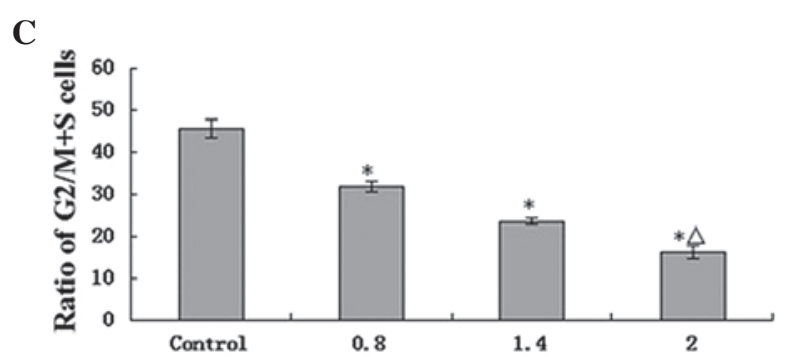

Concentration of Euphorbia Fischeriana Steud (mg/ml)

Figure 2. Induction of apoptosis and G0/G1 arrest in mouse malignant melanoma cells (B16 cells). (A) Fluorescence-activated cell sorting analysis of cell cycles and apoptosis in B16 cells treated for $24 \mathrm{~h}$ with Euphorbia fischeriana Steud at the indicated concentrations. The (B) percentage apoptosis and $(\mathrm{C})$ proportion of cells in the $\mathrm{G} 2 / \mathrm{M}+\mathrm{S}$ phase in cells treated with Euphorbia fischeriana Steud are presented. Euphorbia fischeriana Steud $(0$, $0.8,1.4$ or $2.0 \mathrm{mg} / \mathrm{ml}$ ) induced apoptosis of B16 cells at $24 \mathrm{~h}$ with apoptosis ratios of $13.97 \pm 0.58,24.26 \pm 0.91$ and $41.82 \pm 0.63 \%$ vs. control, respectively $(\mathrm{P}<0.05) .{ }^{*} \mathrm{P}<0.05$ vs. the control group; ${ }^{\wedge} \mathrm{P}<0.05$ vs. every other group.

compared with the control, respectively $(\mathrm{P}<0.05)$. Values of $2.0,1.4$ and $0.8 \mathrm{mg} / \mathrm{ml}$ group, compared with the control group, differed significantly $(\mathrm{P}<0.05$; Fig. 2B). Furthermore, Euphorbia fischeriana Steud also induced a concentration-dependent $\mathrm{G} 0 / \mathrm{G} 1$ arrest and a reduction in the proportion of cells in the G2/M and S phases (Fig. 2C).

Suppression of migration, upregulation of PTEN protein expression and downregulation of Akt activation in B16 cells by Euphorbia fischeriana Steud. A migration assay in fibronectin-coated Transwell chambers revealed that,
A

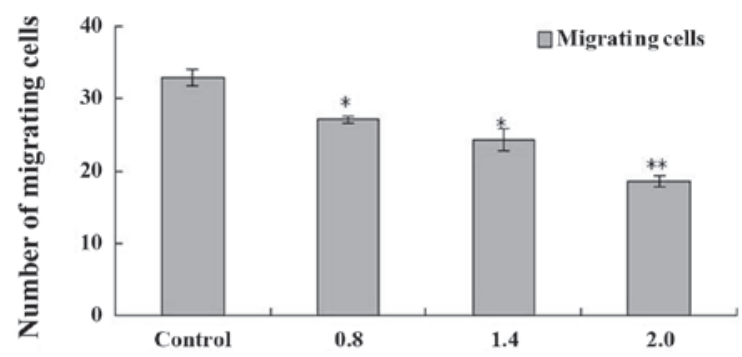

Concentration of Euphorbia Fischeriana Steud (mg/ml)

B

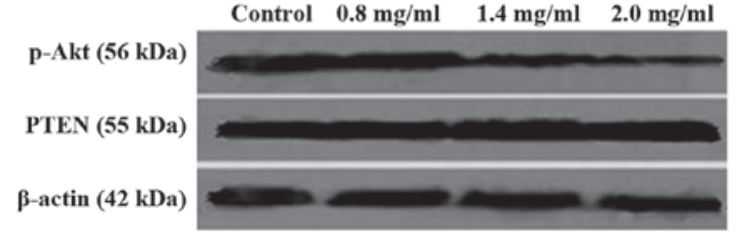

Figure 3. Suppression of migration and pro-matrix p-Akt/PTEN activation in B16 cells by Euphorbia fischeriana Steud. (A) Mouse melanoma B16 cell migration was examined in the presence of Euphorbia fischeriana Steud at the indicated concentrations. Compared with the control, Euphorbia fischeriana Steud at $2.0 \mathrm{mg} / \mathrm{ml}$ significantly decreased migration of B16 cells $(\mathrm{P}<0.01)$. Euphorbia fischeriana Steud at 0.8 or $1.4 \mathrm{mg} / \mathrm{ml}$ also inhibited the migration of B16 cells $(\mathrm{P}<0.05)$. (B) The expression levels of PTEN and p-Akt proteins in each group were analyzed by western blotting. Euphorbia fischeriana Steud at all concentrations tested $(0.8,1.4$ or $2.0 \mathrm{mg} / \mathrm{ml})$ upregulated PTEN and downregulated p-Akt expression levels in B16 cells in a dose-dependent manner. B16 cells treated with Euphorbia fischeriana Steud at different concentrations had significantly reduced ratios of p-Akt to PTEN. For each experiment, three assays were performed. ${ }^{*} \mathrm{P}<0.05 ;{ }^{* *} \mathrm{P}<0.01$, statistically significant vs. control; p-Akt, phospho-protein kinase B; PTEN, phosphatase and tensin homolog.

after $24 \mathrm{~h}$ of exposure to Euphorbia fischeriana Steud with concentrations of $0.8,1.4$ or $2.0 \mathrm{mg} / \mathrm{ml}$, the migration of B16 cells was significantly suppressed with inhibition rates of 17.58, 26.06 and 43.64\%, respectively (Fig. 3A). Western blot analysis confirmed that, compared with the controls, p-Akt protein expression levels were reduced, and PTEN protein expression levels were increased in the cells treated with Euphorbia fischeriana Steud at concentrations of 0.8, 1.4 and $2.0 \mathrm{mg} / \mathrm{ml}$.

Suppression of the mRNA expression of $p$-Akt and MMP-2 in B16 cells by Euphorbia fischeriana Steud. RT-PCR analysis demonstrated that the mRNA expression of p-Akt and MMP-2 in B16 cells following treatment with Euphorbia fischeriana Steud at concentrations of $0.8,1.4$ or $2.0 \mathrm{mg} / \mathrm{ml}$ Euphorbia fischeriana Steud for $24 \mathrm{~h}$ was reduced in a concentration-dependent manner (Fig. 4).

\section{Discussion}

Malignant melanoma is a lethal type of skin cancer, accounting for $80 \%$ of skin cancer mortalities (14). The high degree of malignancy and occurrence in a dormant state, in addition to a strong tendency for distant metastasis, invasion and migration, presents a challenge in the provision of a successful clinical treatment. As a result, the median survival following malignant melanoma invasion or metastasis is 2-8 months (15-17). Current clinical chemotherapy drugs for melanoma demonstrate 

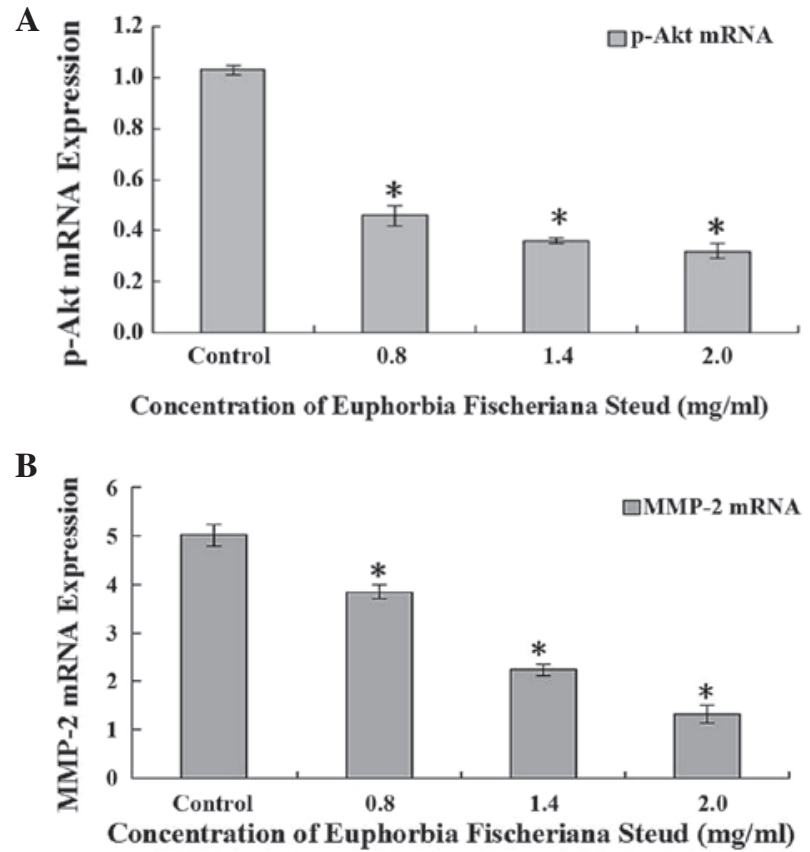

Figure 4. Effects of Euphorbia fischeriana Steud on the mRNA expression levels of (A) p-Akt and (B) MMP-2 in B16 cells. Expression levels of mRNA were detected by reverse transcription-quantitative polymerase chain reaction after cells were treated for $24 \mathrm{~h}$ with Euphorbia fischeriana Steud at 0 (control), $0.8,1.4$ or $2.0 \mathrm{mg} / \mathrm{ml}$. mRNA expression levels were normalized to $\beta$-actin. For each experiment, three assays were performed. The density of the band (normalized to $\beta$-actin) is presented as the mean \pm standard deviation relative to that of the control (designated as 1.00). Significant reductions in mRNA expression levels were obtained for $\mathrm{p}-\mathrm{Akt}(\mathrm{n}=3)$ and MMP-2 ( $=3$ ). * $\mathrm{P}<0.05$ vs. control. MMP-2, matrix metalloproteinase; p-Akt, phospho-protein kinase B.

poor efficacy, with $<20 \%$ being effective (18). Furthermore, adverse effects such as bone marrow suppression and immunosuppression lead to the treatments being intolerable for patients (19). Recent developments in the characterization of certain abnormal cell signal transduction pathways associated with malignant melanoma have indicated the importance and feasibility of their use in the treatment of the aforementioned conditions. Several therapies targeting abnormal signal pathways involved in malignant melanomas have recently been used $(20,21)$, however, their efficacy when administered as a single-agent is poor and the median progression-free survival remains at only 2.8 months (22).

Results from recent studies have revealed that an abnormal absence of the PTEN gene exists in $30-50 \%$ of melanoma cell lines $(23,24)$. Low expression levels of PTEN lead to an ineffective inhibition of Akt activation, resulting in an over-activation of the PI3K/Akt pathway, which promotes the metastasis of tumor cells (25). Activation of the PI3K/Akt pathway may activate the protein $\mathrm{P} 70^{\mathrm{S} 6 \mathrm{~K} 1}$ through the tuberous sclerosis complex 1/2-mammalian target of rapamycin (mTOR) pathway, and thereby promote the reconstruction of actin filaments $(26,27)$. Aberrant activation of mTOR may also increase MMP-2 expression levels, which can cause degradation of the extracellular matrix and lead to promotion of tumor cell metastasis (28). Thus, abnormal activation of the PI3K/Akt pathway in malignant melanoma promotes the migration of tumor cells through the induction of degradation and enhanced motility (29-31). In the present study, it was demonstrated that suppression of the PI3K/Akt pathway greatly contributes to the inhibition of the proliferation and migration of melanoma B16 cells.

Euphorbia fischeriana Steud has been used for the treatment of tumors for numerous years in China. The aforementioned TCM has attracted considerable attention as it strongly inhibits the activity of a variety of tumor cells as a result of a broad spectrum of antitumor properties, while displaying minimal side effects $(12,32)$. In the present study, Euphorbia fischeriana Steud was selected as the raw material for investigation, and water extraction $(2 \mathrm{~g}$ crude drug/ $1 \mathrm{ml}$ extracted liquid) was conducted, with the predominant chemical constituents of extraction being Euphorbia lactones, flavonoids, terpenoids, Euphorbia alcohol and tannins, as identified through pharmacological analysis. Results from numerous basic research studies have demonstrated that Euphorbia fischeriana Steud can function as a strong inhibitor of proliferation and induction of apoptosis in a variety of tumor cell lines (33-35). In addition to its capacity to suppress the proliferation of malignant melanoma B16 cells, Euphorbia fischeriana Steud also demonstrates the ability to regulate the expression levels of factors that are associated with melanoma cell transfer (36). In the present study, the cell signal transduction pathway and molecular mechanisms of Euphorbia fischeriana Steud associated with the inhibition of metastasis of malignant melanoma cells, were examined. Results obtained from studies such as the present one may provide the experimental evidence required for the development of Euphorbia fischeriana Steud in the treatment of malignant melanoma. Furthermore, an understanding of the mechanisms of Euphorbia fischeriana Steud provide the foundation for the identification of other novel natural compounds with low toxicity and high selectivity for the destruction of various cancer cells.

In the present study, it was demonstrated that the aqueous extract of Euphorbia fischeriana Steud inhibited the growth and migration of B16 cells in a dose-dependent manner and induced apoptosis and G0/G1 cell cycle arrest in B16 cells. Euphorbia fischeriana Steud also suppressed the PI3K/Akt signaling pathway in B16 cells through the upregulation of PTEN and downregulation of p-Akt expression levels and also by reducing the mRNA expression levels of $\mathrm{p}$-Akt and MMP-2. To the best of our knowledge, no other reports exist detailing the association between the PI3K/Akt signaling pathway and the inhibitory effects of Euphorbia fischeriana Steud on the growth and metastasis of melanoma B16 cells in vitro, and the underlying mechanisms. The data provided in the current study suggest that Euphorbia fischeriana Steud may have potential in therapeutic and/or adjuvant therapeutic applications for the treatment of human melanoma and other cancers.

In the present study, a series of experiments directed at examining the association and mechanisms between the PI3K/Akt signaling pathway and the inhibitory effects of Euphorbia fischeriana Steud on the growth and metastasis of melanoma B16 cells were performed. The results demonstrate that Euphorbia fischeriana Steud inhibited the growth and metastasis of B16 cells, possibly via modulation of the PI3K/Akt signaling pathway, with upregulation of PTEN 
expression levels and downregulation of p-Akt expression levels.

\section{Acknowledgements}

The present study was supported by grants from the Project of Army Medical Research in Science and Technology (grant no. 06G034), the Nature Science Foundation of China (grant no. NSFC 81370730 and 81571512), the Department of Science and Technology in Shandong province (grant no. ZR2015JL027) and the International Excellent Talent Visitor Scholar Program in 2015.

\section{References}

1. Tsao H, Chin L, Garraway LA and Fisher DE: Melanoma: From mutations to medicine. Genes Dev 26: 1131-1155, 2012.

2. Mateus $\mathrm{C}$ and Robert C: Major therapeutic advances in the treatment of metastatic melanoma. Bull Cancer 99: 619-625, 2012 (In French).

3. Rosenberg E, Horev A and Neulander EZ: Amelanotic malignant melanoma of the penis. A case report and literature review. Arch Ital Urol Androl 84: 42-43, 2012.

4. Mikhnin AE, Tarkov SA and Frolova OS: Cutaneous melanoma in the head and neck region: Current knowledge. Vopr Onkol 58: 19-25, 2012 (In Russian).

5. Grossmann AH, Grossmann KF and Wallander ML: Molecular testing in malignant melanoma. Diagn Cytopathol 40: 503-510, 2012.

6. Kaufman HL: Vaccines for melanoma and renal cell carcinoma. Semin Oncol 39: 263-275, 2012.

7. Lacy KE, Karagiannis SN and Nestle FO: Advances in the treatment of melanoma. Clin Med 12: 168-171, 2012.

8. Bloomfield JG and Tanay MA: Chemotherapy in the community: The importance of patient assessment. Br J Community Nurs 17: 278-283, 2012.

9. Sun YX and Liu JC: Chemical constituents and biological activities of Euphorbia fischeriana Steud. Chem Biodivers 8: 1205-1214, 2011.

10. Wang YB, Huang R, Wang HB, Jin HZ, Lou LG and Qin GW: Diterpenoids from the roots of Euphorbia fischeriana. J Nat Prod 69: 967-970, 2006.

11. Smith ME and Bauer-Wu S: Traditional chinese medicine for cancer-related symptoms. Semin Oncol Nurs 28: 64-74, 2012.

12. Liu J, Li X, Liu J, Ma L, Li X and Fønnebø V: Traditional chinese medicine in cancer care: A review of case reports published in Chinese literature. Forsch Komplementmed 18: 257-263, 2011.

13. Livak KJ and Schmittgen TD: Analysis of relative gene expression data using real-time quantitative PCR and the 2(-Delta Delta C(T)) Method. Methods 25: 402-408, 2001

14. Tremante E, Ginebri A, Lo Monaco E, Frascione P, Di Filippo F, Terrenato I, Benevolo M, Mottolese M, Pescarmona E and Visca P: Melanoma molecular classes and prognosis in the postgenomic era. Lancet Oncol 13: e205-e211, 2012.

15. Espinosa E, Berrocal A, López Martín JA, González Cao M, Cerezuela P, Mayordomo JI and Martín Algarra S; Grupo Español de Melanoma (GEM): Advances in cutaneous melanoma. Clin Transl Oncol 14: 325-332, 2012.
16. Sanford M: Ipilimumab: In previously treated patients with advanced melanoma. Bio Drugs 26: 185-193, 2012.

17. Trinh VA and Hwu WJ: Ipilimumab in the treatment of melanoma. Expert Opin Biol Ther 12: 773-782, 2012.

18. Stratigos AJ, Forsea AM, van der Leest RJ, de Vries E, Nagore E, Bulliard JL, Trakatelli M, Paoli J, Peris K, Hercogova J, et al: Euromelanoma: A dermatology-led European campaign against nonmelanoma skin cancer and cutaneous melanoma. Past, present and future. Br J Dermatol 167: 99-104, 2012.

19. Smalley KS and McArthur GA: The current state of targeted therapy in melanoma: This time it's personal. Semin Oncol 39: 204-214, 2012.

20. Mathew R and Messina JL: Recent advances in pathologic evaluation and reporting of melanoma. Semin Oncol 39: 184-191, 2012.

21. Silva E: Adjunct primer for the use of national comprehensive cancer network guidelines for the surgical management of cutaneous malignant melanoma patients. World J Surg Oncol 6: 54, 2012.

22. Flaherty KT, Hodi FS and Fisher DE: From genes to drugs: Targeted strategies for melanoma. Nat Rev Cancer 12: 349-361, 2012.

23. Aguissa-Touré AH and Li G: Genetic alterations of PTEN in human melanoma. Cell Mol Life Sci 69: 1475-1491, 2012.

24. Wu H, Goel V and Haluska FG: PTEN signaling pathways in melanoma. Oncogene 22: 3113-3122, 2003.

25. Madhunapantula SV and Robertson GP: The PTEN-AKT3 signaling cascade as a therapeutic target in melanoma. Pigment Cell Melanoma Res 22: 400-419, 2009.

26. Meier F, Schittek B, Busch S, Garbe C, Smalley K, Satyamoorthy K, Li G and Herlyn M: The RAS/RAF/MEK/ERK and PI3K/AKT signaling pathways present molecular targets for the effective treatment of advanced melanoma. Front Biosci 10: 2986-3001, 2005.

27. Davies MA: The role of the PI3K-AKT pathway in melanoma. Cancer J 18: 142-147, 2012.

28. Willems L, Tamburini J, Chapuis N, Lacombe C, Mayeux P and Bouscary D: PI3K and mTOR signaling pathways in cancer: New data on targeted therapies. Curr Oncol Rep 14: 129-138, 2012.

29. Bartholomeusz C and Gonzalez-Angulo AM: Targeting the PI3K signaling pathway in cancer therapy. Expert Opin Ther Targets 16: 121-130, 2012.

30. Chen Y, Wang BC and Xiao Y: PI3K: A potential therapeutic target for cancer. J Cell Physiol 227: 2818-2821, 2012.

31. Zhu B and Zhou X: The study of PI3K/AKT pathway in lung cancer metastasis and drug resistance. Zhongguo Fei Ai Za Zhi 14: 689-694, 2011 (In Chinese).

32. Lin H, Liu J and Zhang Y: Developments in cancer prevention and treatment using traditional chinese medicine. Front Med 5: 127-133, 2011.

33. Wang JY, Xu L, Zhang RX and Lao L: Traditional chinese medicine for cancer pain. Zhong Xi Yi Jie He Xue Bao 9: 129-134, 2011 (In Chinese).

34. Zhou TX, Bao GH, Ma QG, Che CT, Lv Y, Wang C and Zheng QT: Langduin $\mathrm{C}$, a novel dimeric diterpenoid from the roots of Euphorbia fischeriana. Tetrahedron Lett 44: 135-137, 2003.

35. Wang JH, Zhang K, Niu HY, Shu LH, Yue DM, Li D and He P: Jolkinolide B from Euphorbia fischeriana Steud induces in human leukemic cells apoptosis via JAK2/STAT3 pathways. Int J Clin Pharmacol Ther 51: 170-178, 2013.

36. Pon D, Wang Z, Le KN and Chow MS: Harnessing traditional Chinese medicine to improve cancer therapy: Issues for future development. Ther Deliv 1: 335-344, 2010. 